\title{
Using Popular Film As A Teaching Resource In Accounting Classes
}

Darlene Bay, Brock University, Canada

Sandra Felton, Brock University, Canada

\begin{abstract}
This paper describes a pedagogical experiment that used feature films in a senior accounting class to stimulate development of student competencies and raise ethical issues. Rather than being content driven, this active learning technique focuses on skills development, while engaging the students' emotions in the learning process. Encompassing three types of knowledge (conceptual, procedural and meta-cognitive), the exercises explore concepts of internal control, corporate governance and business ethics. They provide opportunities for accounting students to practice the higher level cognitive skills in Bloom's (1956) taxonomy and aim to foster students' emotional commitment to ethical decisionmaking. Students reacted positively to these activities, finding them most helpful in clarifying the impact of ethical issues. We observed significant differences between the beliefs of groups who participated in these exercises and those who did not, suggesting that this activity can be an effective tool for engaging students and influencing their perceptions about accounting issues.
\end{abstract}

Keywords: Teaching Accounting; Active Learning Technique; Films; Movies

\section{INTRODUCTION}

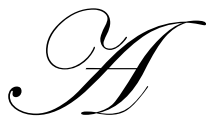

ctive learning techniques have become of increasing interest to accounting educators, as they move to implement the suggestions of the Accounting Education Change Commission and to keep abreast of pedagogical advances in other fields. The learning activities described in this paper were motivated by the recommendations for improving accounting education set out by Albrecht and Sack in Accounting Education: Charting a Course through a Perilous Future (2000). This monograph criticizes traditional accounting education as too narrow as it "does not prepare students for the ambiguous business world they will encounter upon graduation" (p.41). It finds that traditional accounting pedagogy "often lacks creativity" (p.43) and that accounting courses "do not deal enough with values, ethics, and integrity" (p.51). It stresses the importance of developing analytical/critical thinking competencies (p.56), and complains that our traditional "education models focus too much on content at the expense of skill development" (p.43).

In response to these criticisms, we describe a "nontraditional" creative learning activity that uses feature films in an upper level accounting course to explore concepts of internal control, corporate governance and business ethics. We employ popular cinema as an instructional tool to stimulate critical thinking, and increase accounting students' sensitivity to issues involving ambiguity, integrity and personal values. The film exercises are designed around educational objectives recommended by previous researchers to: 1) address different cognitive processes, 2) encourage acquisition of different types of knowledge, 3) raise ethical questions, and 4) engage student emotions in the learning process. Our findings suggest that these activities are effective in motivating students and influencing their perceptions about accounting issues. This study's contribution to improving the quality of accounting education is to offer instructors a new learning technique that can provide opportunities for students to practice critical thinking competencies and other cognitive skills and to explore ethical issues.

We begin with a summary of the theoretical framework of educational objectives that guided the design of our learning activities, including a description of the accounting course in which we used this pedagogy. This is followed by a literature review of previous studies about using popular cinema as an instructional resource in the business curriculum. We then describe our three film exercises and the results of using this learning activity. We conclude with our assessment of its success and our suggestions for future improvements in using this technique. 


\section{THEORETICAL FRAMEWORK OF EDUCATIONAL OBJECTIVES}

We employed our film exercises in a senior university accounting course entitled Integration and Problem Solving, which is taken only by fourth year accounting majors. Focused more on process than content, the course helps students integrate knowledge acquired in earlier years from various sub-disciplines of accounting (such as financial and managerial accounting, information systems, auditing, taxation and accounting ethics).

\section{Cognitive Objectives}

We organized our exercises around Bloom's (1956) taxonomy, which describes six levels of cognitive development and suggests that educators should provide experiences conducive to improving students' skills at each stage. Recently, Anderson and Krathwohl (2001) have refined Bloom's taxonomy by marrying his different levels of cognitive processes with the concept of different types of knowledge to produce a cognitive matrix. One dimension of the matrix describes six stages of cognitive development that become increasingly more complex (remember, understand, apply, analyze, evaluate, create), while the second dimension defines four kinds of knowledge (factual, conceptual, procedural, meta-cognitive). Factual knowledge refers to the bits of data one acquires when memorizing discrete facts or new terminology; for accounting, this might include learning the names of new accounts or the definition of a cost pool. Conceptual knowledge emphasizes relationships and structure, such as learning the accounting equation. Procedural knowledge involves comprehension of important methods and understanding when to apply them, such as learning how to develop an effective internal control procedure. Metacognitive knowledge is knowledge about learning and thinking, such as self-knowledge or understanding about biases that may influence decision making. This type of knowledge is not discipline specific and includes skills applicable to a variety of educational settings.

We apply this cognitive matrix for the current project, as it provides a rich description of educational objectives and allows us to visually assess which objectives are being addressed by our learning activities. For our fourth year accounting course, we tried to design activities that would encourage students to practice some of the higher ranked skills on the cognitive dimension of the matrix taxonomy. In addition, the course is intended to present opportunities for problem solving and integration, rather than acquiring factual knowledge. Therefore, we selected exercise topics to illustrate the upper three levels in the knowledge dimension of the matrix: corporate governance (conceptual knowledge); internal control (procedural knowledge); and accounting ethics (metacognitive knowledge). In Table 1, the objectives of the three exercises described later in this paper have been mapped into the taxonomy matrix.

Table 1: The Taxonomy Matrix

\begin{tabular}{|l|c|c|c|c|c|c|}
\hline \multirow{2}{*}{ The Knowledge Dimension } & \multicolumn{5}{|c|}{ The Cognitive Process Dimension } \\
\cline { 2 - 7 } & $\mathbf{1 . ~ R e m e m b e r}$ & $\mathbf{2 .}$ Understand & 3. Apply & 4. Analyze & 5. Evaluate & 6. Create \\
\hline A. Factual Knowledge & & & & & & \\
\hline B. Conceptual Knowledge & CG1 & CG1 & CG1 & CG2 & CG3 & \\
\hline C. Procedural Knowledge & IC1 & IC1, IC3 & IC1 & IC4 & IC2 \\
\hline D. Meta-Cognitive Knowledge & E1, E3 & & E1, E3 & E2 & E4 & \\
\hline
\end{tabular}

CG1 - Apply management theories, such as the stakeholder model and agency theory, in a "real life" setting (also requires the student to remember and understand theories taught in prior courses).

CG2 - Analyze similarities and differences in how two films portray these management theories.

CG3 - Evaluate how closely the action portrayed in the movies corresponds to the theories taught in class and to the real world of business.

IC1 - Identify internal control weaknesses in the film (requires the student to remember and understand theory learned in prior courses and apply it to a new situation)

IC2 - Propose (create) alternative procedures to address internal control weaknesses

IC3 - Identify (understand) the skills exemplified by a successful con man.

IC4 - Analyze how the skills of a successful con man resemble or differ from those needed to be a successful business person.

E1 - Identify the ethical decision making process of the movie accountant (also requires the student to remember ethics theories from previous courses and apply them to this situation)

E2 - Analyze the similarities and differences of ethical decision making for personal versus business decisions.

E3 - Identify the values espoused by the accountants in the movies (also requires the student to remember value theory and apply it to this situation)

E4 -Evaluate the values of the accountant portrayed in relation to your own values 


\section{Affective Objectives}

The same group that developed Bloom's cognitive taxonomy also proposed affective educational objectives (Krathwohl et al., 1964). An affective objective describes an emotional state, such as motivation. While one can discuss the cognitive and affective separately, the two are nearly always entwined. For example, learning cannot take place without the proper motivation.

Until recently, emotions were often ignored, if not actively avoided, in business research and education (Ten Bos and Willmott, 2001; Griseri, 2002; MacPhail, 2004). The ideal was the rational decision maker of economic theories; emotions were seen as impediments to effective business decisions. Recent findings challenge the assumption that emotions disrupt cognitions (Klein, 2002; Connelly et al., 2004). It may be impossible and undesirable to disentangle the rational from the affective, as emotions are important to corporate success (Solomon, 1993; McPhail, 2001; Ten Bos and Willmott, 2001). Practitioners are also more aware of the potential uses of affect, as shown by their growing interest in the concept of emotional intelligence.

Educators often recommend active learning techniques as a way to engage student emotions in the learning process. This may be especially important in teaching ethics to accounting students, as emotions have a direct impact on the process of ethical decision making (Schweitzer and Gibson, 2008; Connelly et al., 2004). Increased cognitive ethical development does not necessarily translate into increased ethical intentions, and the moderating variable may be emotions (Thorne, 2001; Gaudine and Thorne, 2001; Henrik 2008). Teaching theories of ethical decision making is unlikely to increase ethical behavior in business (McPhail, 2004; Griseri, 2002), unless we increase the emotional involvement of students, rather than just their cognitive understanding (McPhail, 2004; Griseri, 2002). McPhail (2001) suggests that accounting ethics education include affective goals and recommends using real life case studies, film, literature and role playing to foster the student's emotional commitment to ethical behavior.

\section{PRIOR RESEARCH ON USING POPULAR FILM AS A TEACHING RESOURCE}

Several previous studies suggest that the popular cinema can be a useful tool for helping business instructors to achieve their educational objectives. At the lowest levels of the cognitive taxonomy, films can help students to remember and understand course material. Movies can expose students to organizational environments beyond their own experience, enabling them to observe theoretical processes in action (Berger and Pratt, 1998). By presenting a visual portrayal of an abstract concept, a film can imbue it with a greater sense of reality, and illustrate its application in different situations (Champoux, 2004). Visual imagery is an important memory aid (Sexton, 2006) and students are more likely to remember concepts that have been grounded in the tangible reality of a story (Gaiacalone and Jurkiewicz, 2001).

Popular films can also be used to develop some of the higher level skills from the cognitive hierarchy, as they stimulate discussion and provide opportunities for students to apply concepts to a new situation, and analyze and evaluate complex relationships. Films often communicate ideas on several levels, conveying the paradox and ambiguity of modern cultures, and helping students recognize alternative perspectives and develop insights into contradictory behaviors (Mallinger and Rossy, 2003). Buchanan and Huczynski (2004) argue that film narratives are "theory laden," presenting a sequence of events that explains outcomes by showing the link between actions and consequences. Even fictional stories can be a valid source of knowledge that can expose new theoretical relationships and question established thinking. Feature movies can be used to integrate liberal arts concepts into the business curriculum and bridge the gap between general education and business courses (McAdams and Duclose, 1999). Thus, this pedagogy fits well with the educational objectives set out by accreditation bodies such as the Association for the Advancement for Colleges and Schools of Business, which stress the importance of general education in broadening the perspective of business students.

Several studies find popular cinema to be a useful tool for focusing attention on the complexities of business ethics and the nuances of ethical decision-making. Films show how actions are interconnected and how people and institutions are interdependent, helping students understand that a small or isolated ethical act may affect a larger whole and that business and non-business are not distinct realities (Gaiacalone and Jurkiewicz, 2001). 
Rokeach (1973) proposes that we can infer the values an individual regards as most important by observing the person's actions. Since film tends to be action focused, it provides a useful medium for analyzing the relationship between (un)ethical behavior and the values espoused by a decision maker. Prior researchers have used movies to strengthen students' ethical responsiveness through value clarification, personal assessment and self-knowledge (Berger and Pratt, 1998; Champoux, 2004).

In addition to assisting educators to meet their cognitive objectives, popular cinema can also help in achieving affective educational objectives in the classroom. Because this medium is familiar and enjoyable for students, it is more likely to hold their interest and motivate them to learn. Film techniques, such as camera angles, close-up shots, editing, sound and special effects can heighten the drama of the decision-making process and create scenes more powerful than those found in reality (Champoux, 2004). Gaiacalone and Jurkiewicz (2001) argue that popular films are particularly suitable for integrating ethics into the business curriculum, as they engage a variety of senses in the learning experience and can arouse more depth of feeling among students than can be achieved through case studies. Psycho-physiological studies indicate that movies engage the audience more intensely than other forms of communication, even evoking reactions such as an upset stomach or sweating palms (Grant, 1986).

Previous research indicates that popular cinema can be a useful resource for teaching many subjects in the business curriculum, including business communications (Berger and Pratt, 1998), organizational behavior and principles of management (Serey, 1992; Bumpus, 2005), leadership (Buchanan and Huczynski, 2004), corporate finance (Nosfsinger, 1995), business ethics (McAdams and Duclos, 1999; Gaiacalone and Jurkiewicz, 2001), crosscultural issues in business (Mallinger and Rossy, 2003), strategic decision-making (Buchanan and Huczynski, 2004), economics (Sexton, 2006; Leet and Houser, 2003), and game theory (Dixit, 2005). However, it would appear that accounting educators have not kept pace with the pedagogical innovations of their business colleagues in this regard, as we did not find any articles about feature films being employed as an instructional resource in this discipline. Dirsmith (1983) does report success using Milgram's psychological film Obedience to explore the concept of independence in an auditing class. While Obedience is a filmed experiment, rather than a mainstream movie, Dirsmith's paper suggests that even a film that does not specifically involve a business setting may be effective in raising issues relevant to accounting students.

The purpose of our study is to extend previous research and to experiment with a creative pedagogy that employs popular cinema as an instructional resource to address three accounting topics. In the remainder of the paper we describe our film exercises and access their effectiveness in providing opportunities for active learning in an upper level accounting course.

\section{FILM EXERCISES}

The learning activities detailed below were included in three sections of a fourth year accounting capstone course, Integration and Problem Solving, described earlier in this paper. Depending on the topic, these exercises could be incorporated into other courses such as auditing or accounting theory. Alternatively, other films could be employed similarly to study other accounting topics.

In choosing the movies used in this assignment, the authors following the selection criteria recommended by previous researchers. Buchanan and Huczynski (2004) advise that the films should be plausible, have aesthetic appeal, and relate to the educational objectives of the course. They also recommend using contemporary films, as older "classics" may have less credibility with student groups. To maximize the probability of engaging student interest, we selected nine movies with theses relevant to accounting students. Released between 1983 and 2003, all feature famous actors, enjoyed box office success, and won critical acclaim.

For each exercise, the instructor required students to watch one or more films outside of class time as a homework assignment. Initially, the instructor provided only general (minimal) guidance as to what students should look for when watching the movie(s), but did not assign specific detailed questions to be prepared before class. The intention was to leave the initial viewing somewhat unstructured in order to encourage a more spontaneous engagement and interaction in the class discussion, providing a better opportunity for students to practice and develop their higher level cognitive skills. The film exercises, including participation in related class discussions, constituted approximately $10 \%$ of the total grade in the course. 
Below we identify for each exercise: 1) the topic, 2) the knowledge dimension addressed, 3) the film(s) assigned, 4) the objectives of the exercise, including the cognitive processes addressed (shown in italics), 5) the film plot and rationale for its inclusion in the exercise, 6) the discussion questions (in bold at the beginning of each paragraph) used to achieve the objectives, and 7) a summary of how the students responded.

\section{Exercise I: Corporate Governance (CG)}

\section{Topic: Knowledge Dimension: Conceptual Knowledge}

Films: Barbarians at the Gate (1993) starring James Garner and Jonathan Pryce Wall Street (1987) starring Charlie Sheen and Michael Douglas

Objectives: CG1 - Apply management theories, such as the stakeholder model and agency theory, in a "real life" setting (also requires the student to remember and understand theories taught in prior courses).

CG2 - Analyze similarities and differences in how the two films portray these theories.

G3 - Evaluate how closely the action portrayed in the movies corresponds to the theories taught in class and to the real world of business.

Both films involve corporate takeovers and highlight unbridled greed in corporate America. Barbarians at the Gate is a very realistic portrayal of the well publicized takeover of RJR Nabisco by Kohlberg Kravis Roberts \& Co. (KKR) in 1988. It relates the struggle between two men to execute a leveraged buyout of the company: Ross Johnson (James Garner), the Nabisco CEO who likes to overindulge in company perks, and Kravitz (Jonathon Pryce), a corporate raider who manages to force him out. Both men are backstabbing Machiavellians, who show no concern for others who may suffer the consequences of their extremely aggressive business practices. In Wall Street, Gordon "greed is good" Gecko (Michael Douglas), a ruthless takeover artist, recruits Buddy Fox (Charlie Sheen), a young Wall Street trader, to join him and use any and all means to seek out private information to be used in securing better deals. When Gecko moves to take over the firm where Buddy's father works, threatening the jobs of the father and his friends, Buddy decides to double cross Gecko, saving the firm but landing both men in prison. While neither film is specifically about an accountant, we included these movies in our learning exercises because both have clear implications for accounting (the role of public versus public information) and for corporate governance, a topic very relevant to the accounting profession. Both clearly portray the roles of the CEO and other members of the management team, the actions of the board of directors and the influence and welfare of the shareholders. In both films, the proposed action has the potential to cost many jobs, so that employees feature as important stakeholders in the firm.

All students were required to watch both films outside of class time and were told to look for examples of any theories they had studied in previous accounting courses. However, the instructor made no mention of any specific theories to consider. The students were also asked to be alert for any mention of accounting information and the role (if any) that it played in the story.

The class discussion focused on the following questions:

- What examples did you find of accounting theories being portrayed in the movies?

The class easily identified examples in the film narratives of agency theory, stewardship theory, the efficient market hypothesis, information asymmetry and moral hazard. ${ }^{1}$ Students were especially interested in the portrayals of the divergence between the interests of management and those of shareholders. In both films, management shows very little concern for the shareholders and their references to the interests of other stakeholders appear very cynical.

\footnotetext{
${ }^{1}$ These are concepts that students had studied earlier in their accounting theory course, covered in the textbook Financial Accounting Theory $4^{\text {th }}$ edition by William Scott (2006).
} 
- What are the similarities and differences in the two movies with respect to how the theories were portrayed?

The students observed that both films portray opportunistic behavior on the part of management. Both (but particularly Barbarians at the Gate) show managers living a lavish lifestyle at the firm's expense. The class agreed that both movies provide excellent illustrations of the effects of information asymmetry. In each case, the party that manages to acquire the best information is able to use it to defeat its competitors (or other stakeholders in the firm). Students struggled to find differences between the two films. One of the more insightful comments was that Barbarians at the Gate shows the takeover from management's perspective, while Wall Street takes an investor's perspective.

- What was the role of the board of directors (BOD) and how much power did they seem to exert?

In both movies, the class saw the BOD as fairly easily manipulated by the stronger, more capable, better informed CEO. The students observed a few instances where the BOD was attempting to provide some checks on the behavior of the CEO, but not many examples to show it had been successful. In both movies, it was clear that incentives, stock options and monitoring by the BOD were not sufficient to control the opportunistic behavior of management.

- What was the role of accounting in the two movies?

The students noted that in Wall Street, the only trader who relies on accounting information to make his trading decisions is almost a comedic character and not as successful financially as his counterparts who use less traditional means of gathering information. In Barbarians at the Gate, it is clear that published financial information was not sufficient for making decisions about share prices and that the current management team had a huge advantage due to information asymmetry over the outsiders.

- $\quad$ How well do the films portray the theories taught in class and how closely do they reflect what happens in the "real" world of business?

The class concluded that these two films depicted quite well many concepts that they had studied in previous accounting courses. However, students felt that they would need to watch many more movies in order to draw a conclusion about whether this was typical of Hollywood's representation of these issues. The class was almost equally divided about how closely the films reflected the "real" business world: some felt sure that management rarely considers the best interests of the shareholders and others believed that most managers attempt to advance the owners' welfare when performing their jobs. As regards how much actual power "real" BODs wield and how well they protect the interest of the shareholders, the students concluded that they may be stronger than depicted in the films, since these stories are based on exceptional, well known instances of failure of corporate governance that may not reflect the average firm or the average manager. As might be expected, the accounting students were inclined to believe that accounting information is more important than depicted in these movies. They concluded that Hollywood does not really understand the role of accounting information in capital markets and therefore the films do not accurately represent the value it provides.

\section{Exercise II: Internal Control (IC)}

Knowledge Dimension: $\quad$ Procedural knowledge

Film: Catch Me If You Can (2003) starring Leonardo Di Caprio and Tom Hanks

Objectives: IC1 - Identify internal control weaknesses shown in the film (requires the student to remember and understand theory learned in prior courses and apply it to a new situation)

IC2 - Propose (create) alternative procedures to address internal control weaknesses 
IC3 - Identify (understand) the skills exemplified by a successful con man.

IC4 - Analyze how the skills of a successful con man resemble or differ from those needed to be a successful business person.

Catch Me If You Can is a film about real-life con man, Frank Abagnale (Leonardo Di Caprio). We selected this movie because it illustrates the consequences that can occur when internal controls break down in various areas such as hiring practices, supervision of employees, safeguarding of fixed assets, cash disbursements, etcetera. In the film, Abagnale takes advantage of control weaknesses to steal money, acquire a position for which he is not qualified or get out of potentially difficult situations. He cashes bad checks, obtains free airplane rides, and passes himself off as a doctor, a pilot and a lawyer, all the while staying several steps ahead of the FBI agent (Tom Hanks) who is trying to catch him. After Abagnale is finally caught and imprisoned, the FBI recruits him to work for the agency, helping to catch other con men.

All students were required to watch the film outside of class time and were told to note as many internal control weaknesses as they could find. The class discussion focused on the following questions:

- What internal control weaknesses did you identify?

The class was able to generate a substantial list of internal control weaknesses including lack of control over capital assets, failure to check credentials and references, improper training and supervision of personnel, checks that were too easy to counterfeit and many others. When asked to identify commonalities in the situations depicted, the students noted that apparently effective internal controls often could be circumvented by an employee whose vigilance lapses due to the charm of the con man or a desire to help someone who appears to need it.

- $\quad$ Propose alternative procedures to address these internal control weaknesses.

The class had a more difficult time proposing solutions to the weaknesses. For most of the control procedures proposed, a colleague could suggest how one could circumvent the system.

- What skills or characteristics enable Abagnale to be so successful in conducting this fraud?

Students managed to generate a good list that included: charm, ability to learn quickly, flexibility, good sense of timing, awareness of surroundings, ability to relate well to people, good memory, and ability to appear as people expected and/or wanted him to be.

- Analyze how the skills of a successful con man resemble or differ from those needed to be a successful business person.

Students recognized that the skills that enabled Abagnale to conduct his fraud included many qualities that would be an asset to any business person. The class identified items in the list that sounded negative and reworded them in a positive manner. For example, "manipulative" became "ability to understand what people want and use that to achieve business goals". A discussion ensued about the difference between a con man who possesses these traits and a successful business person who has the same characteristics. The class concluded that any knowledge or skill can be used effectively within or outside of the existing system. What distinguishes the successful businessman from the successful con man, they decided, may rest solely upon the ethical character of the individual.

\section{Exercise III: Ethics (E)}

Knowledge Dimension: Meta-Cognitive Knowledge

Movies: Local Hero (1983) starring Burt Lancaster and Peter Riegert

Midnight Run (1988) starring Robert DeNiro and Charles Grodin 
The Untouchables (1987) starring Kevin Costner and Robert DeNiro

Shallow Grave (1995) starring Kerry Fox, Ewan McGregor and Christopher Eccleston

Simple Plan (1998) starring Bill Paxton and Billy Bob Thornton

Boiler Room (2000) starring Giovanni Ribisi, Ben Affleck and Vin Diesel

Objectives: E1 - Identify the ethical decision making process of the movie accountant (the student must remember ethics theories from previous courses and apply them to this situation)

E2 - Analyze the similarities and differences of ethical decision making for personal versus business decisions

E3 - Identify the values espoused by the accountants in the movies (the student must remember value theory and apply it to this situation)

E4 -Evaluate the values of the accountant portrayed in relation to your own values

Affective Objective: Develop students' appreciation for how the actions of one person may affect others, sometimes in unintended ways

Each of these movies (except Boiler Room) portrays an accountant who faces an ethical dilemma. In Local Hero the accountant, a respected community leader in a small Scottish town, is asked to broker a deal that would result in a large corporation buying out the town and converting it into a terminal for oil tankers. Midnight Run follows the adventures of Jonathon Mardukas, an accountant who is being pursued by both the mafia and the law, after he embezzles \$15 million from the mob and gives most of it to charity. The Untouchables is based on the true story of how the FBI eventually brought down Al Capone on charges of income tax evasion; the accountant who conceives this idea becomes a member of the FBI team and participates in the violent pursuit of the infamous gangster. Both Shallow Grave and A Simple Plan involve stories of accountants who are convinced by their friends to keep large sums of cash that fall into their possession when the owners of the money die unexpectedly. In both cases it turns out that the money is linked to criminal activities and the decision to keep it brings tragic consequences. Boiler Room was included in this exercise at the recommendation of one of the students. The film portrays an investment dealer who works in the "boiler room" of a seedy brokerage firm, making high pressure calls to scam investors into buying worthless shares. Although the protagonist here is an investment dealer rather than an accountant, we have included him in the discussion of "accountant" characters described below.

The popular films that we chose for this exercise portray accounting characters facing dramatic situations far removed from their everyday routine; these unexpected circumstances present opportunities for individuals with integrity to rise to the challenge and become leaders, while others succumb to temptation and fall into disgrace. Obviously, these stories depict events that an accountant might never expect to encounter in professional life. There are several reasons why we intentionally selected films that would require our accounting classes to explore ethical dilemmas that arise outside of the normal workplace. First, we believe that challenging students to think beyond their usual horizons presents new opportunities for critical thinking and analysis. Second, this helps students to appreciate that the decision making process for dealing with ethical issues encountered at work is not separate and distinct from that required in everyday life. Third, an important reason for using popular movies as an instructional resource is to motivate students to learn by capturing their interest and stirring their emotions. Films that depict the consequences of stealing from the mafia, or of keeping money that does not belong to you, can create scenes more powerful than those found in everyday reality and heighten the students' engagement in the drama of the ethical decision-making process. No matter what the particular setting of the plot, we believe that our educational objective is met if a movie stimulates students to analyze the complexities of ethical decision making, and examine their own value structures. Lastly, we note that other educators have reported success in teaching various subjects using films with stories far removed from situations that their students are likely to encounter in the workplace. For example, Huczynski and Buchanan (2004) use a film about a $16^{\text {th }}$ century English queen (Elizabeth) and one about a scientist 
who decodes an extra-terrestrial message (Contact) to teach leadership and organizational process. Giacalone and Jurkiewicz (2000) recommend a diverse list of films with "non-business" narratives for teaching ethics to business students, such as The Lion King, Saving Private Ryan, and To Kill a Mockingbird.

Each student was assigned to watch two of the films in the ethics exercise. Students were asked to summarize the ethical dilemma presented in each movie that they watched. Those summaries were posted on-line at least two days prior to the class discussion, so that all students had an opportunity to read them in advance. At the beginning of the class discussion, one student summarized the ethical dilemma in each movie. The instructor asked students to focus on the ethical dilemma presented, and try to determine how the protagonists made their decisions. In addition, students were to attempt to identify the values espoused by the accountant characters. Prior to this exercise the instructor had introduced the class to Rokeach's (1973) values survey and the value rankings that were typical of some groups of accountants or accounting students.

The class discussion focused on the following questions:

- What was the ethical decision making process taken by the accountants in the movies?

Students were able to identify a couple of cases where the film character seemed to be applying the six step decision making model they had learned in their business ethics course. However, in other cases, they observed that the accountant seemed to be reacting unthinkingly and that each attempt to get rid of the problem resulted in a further, often escalating dilemma. The consensus was that no decision process was guaranteed to result in a better outcome and that often ethical dilemmas get "solved" almost by accident. However, the class was clearly more approving of those characters who had attempted to make their decisions carefully.

- $\quad$ Analyze the similarities and differences of ethical decision making for personal versus business decisions.

The students struggled with this question. They felt that ethical decisions involving one's personal life were somehow different from those at work, but they could not articulate what the differences were. Although the instructor was not particularly satisfied with the conclusion of this discussion, perhaps airing these ideas made students more open to the possibility that these behaviors were not as independent as they had originally assumed.

- $\quad$ As displayed by their actions, what values did the accountant characters espouse?

Of course, the answers varied here, depending on the movie being discussed. The students agreed that nearly all the accountants exhibited strong values of friendship and family. Most were goal-oriented and wanted to live a comfortable life. All valued their careers and wanted to be perceived as competent. These values, which tend to be personal and competency based, are similar to those which prior researchers have found to be espoused by "real life" accountants and accounting students (Swindle et al., 1987; Pinac-Ward et al., 1995; Eaton and Giacomino, 2000). However, the class saw little evidence that honesty, a value usually associated with accountants, was depicted as important to the film characters. In addition, the students pointed out two instances in which the values stated by the accountants clearly conflicted with the values that one would infer from their actions. The students concluded that, just as some of them did not necessarily agree with the values of "typical" accountants, they could not expect the film characters to conform completely to some "accountant" norm. One student remarked that the variety of values depicted by the film accountants suggests that the image of the profession may not onedimensional.

The last two discussion questions were intended to encourage students to relate their own values to those of the accountants portrayed in the movies.

- Which of the film accountants do you regard as heroes and which are not?

In some cases, there were strong disagreements here. The accountant who was killed while helping to capture Al Capone was widely called heroic, although some students disapproved of his willingness to engage in a gun battle with the mob. Some believed the accountant who stole money from the mafia to give to charity was 
helping to achieve justice, while others felt that stealing was wrong no matter who was the victim. Few considered as heroes the accountants who found money and decided to keep it, although several students admitted that they probably would have done the same. Others, however, recounted times they had found money or other valuable items and had returned them.

- Which film characters do you like and why?

The lack of agreement was even more pronounced for this question. The class had better luck reaching a consensus when they tried a different approach and attempted to decide which characters the filmmaker had intended to portray as likeable. Most had a very difficult time articulating what made them like or dislike a certain character. Those who the class decided had acted ethically were no more likely to be admired than those who had behaved unethically. The heroes did not necessarily fare any better than the villains. The students concluded that defining the term "like" might be important before addressing this question. Several definitions were proposed such as "would be friends with," "approve of," and "feel empathy with." Even these adjustments did not result in agreement.

\section{IMPACT ON LEARNING}

In order to assess whether the exercises had an impact on the students' learning and attitudes, we administered a survey near the end of the course in which the exercises were used. For comparison purposes, one year later we administered the same survey in the same course in which the exercises were not used. We tested differences between the two groups using two tailed t-tests. The responses are shown in Tables 2 through 4 . For all three exercises, the students believed that the movies were helpful. The ethics exercise appears to be most popular, while the internal control exercise was the least popular, although still rated highly.

Table 2: Student Responses to Corporate Governance Exercise

\begin{tabular}{|c|c|c|c|}
\hline Statement & Class Average & Control Average & P Value \\
\hline $\mathrm{N}$ & 88 & 86 & \\
\hline $\begin{array}{l}\text { Watching the movies helped me think more clearly about } \\
\text { corporate governance. }\end{array}$ & 3.34 & NA & \\
\hline $\begin{array}{l}\text { Boards of directors are generally effective in protecting } \\
\text { shareholder interests. }\end{array}$ & 2.78 & 3.38 & .000 \\
\hline $\begin{array}{l}\text { Most of the time management and the board of directors jointly } \\
\text { can be expected to protect the interests of important stakeholder } \\
\text { groups such as employees. }\end{array}$ & 3.29 & 3.51 & .145 \\
\hline
\end{tabular}

Average is the average response on a 5-point scale anchored by 5 (strongly agree) and 1 (strongly disagree).

$\mathrm{P}$-values are the result of 2 tailed t-test of differences of means.

Students who participated in the corporate governance film exercise are significantly more skeptical $(\mathrm{p}=$ .000) than those in the control class about the ability of the board of directors (BOD) to protect the shareholders. This is perhaps surprising, as one might have expected all students to be quite cynical about the efficacy of the BOD, given the publicity about repeated corporate scandals of recent years and the degree to which they have been discussed in many classes. It seems the movie exercise made the failures real to the students in a way that simply talking about them could not.

Table 3: Student Responses to the Internal Control Exercise

\begin{tabular}{|c|c|c|c|}
\hline Statement & $\begin{array}{c}\text { Class } \\
\text { Average }\end{array}$ & $\begin{array}{l}\text { Control } \\
\text { Average }\end{array}$ & P Value \\
\hline $\mathrm{N}$ & 88 & 86 & \\
\hline Watching the movies helped me understand internal control issues better. & 3.11 & NA & \\
\hline It is difficult to circumvent good internal controls procedures. & 2.93 & 3.38 & .001 \\
\hline $\begin{array}{l}\text { The attitudes of the employees in the firm have a strong impact on how effective } \\
\text { internal control procedures are. }\end{array}$ & 4.20 & 4.38 & .056 \\
\hline
\end{tabular}

Average is the average response on a 5-point scale anchored by 5 (strongly agree) and 1 (strongly disagree).

$\mathrm{P}$-values are the result of 2 tailed t-test of differences of means. 
Students who participated in the film exercise are significantly more likely $(\mathrm{p}=.002)$ than those in the control group to accept that internal control procedures can be thwarted. Thus, this learning activity appears to have been effective in making them more alert to the possibility that even good internal controls can be circumvented and assisting them to develop a higher degree of professional skepticism. Both groups strongly agree that employee attitudes impact the effectiveness of controls, but the students who participated in the movie exercise agreed a little less $(\mathrm{p}=.056)$, indicating that they had perhaps also thought of other ways that internal control can be circumvented.

Table 4: Student Responses to the Ethics Exercise

\begin{tabular}{|c|c|c|c|}
\hline Statement & Class Average & Control Average & P Value \\
\hline $\mathrm{N}$ & 88 & 86 & \\
\hline $\begin{array}{l}\text { Watching the movies provided me with a clearer understanding of the } \\
\text { personal impact of some ethical issues. }\end{array}$ & 3.63 & NA & \\
\hline $\begin{array}{l}\text { An action should be assessed to be ethical or unethical depending on } \\
\text { its outcome. }\end{array}$ & 2.42 & 2.12 & .023 \\
\hline $\begin{array}{l}\text { A decision can be determined to be unethical or ethical based on the } \\
\text { reasons for the decision. }\end{array}$ & 3.60 & 3.59 & .692 \\
\hline
\end{tabular}

Average is the average response on a 5-point scale anchored by 5 (strongly agree) and 1 (strongly disagree).

$\mathrm{P}$-values are the result of 2 tailed t-test of differences of means.

The ethics exercise led to the most unstructured discussion and the widest disagreement among the students. The fact that the students believed it to be useful provides some evidence that accounting students do not regard their ethical understanding as fully developed, and that they view a discussion of ethics as still helpful even in the upper years of their undergraduate program. Both the students that participated in the movie exercise and those that did not, on average, are more inclined to judge the ethical nature of a decision based on the reason for the decision, rather than based on the outcome of the decision. However, students who participated in the film exercises are significantly more likely to believe that one should consider the consequences of a decision in evaluating its ethical nature. To some degree, this may be due to the class discussion of film protagonists whose decisions had unintended consequences. Observing the results of decisions that were poorly thought out by accounting characters may have highlighted for students the necessity of taking responsibility for the outcome of one's actions.

Finally, we gathered data about the students' affective responses to the movie exercises. The results are reported in Table 5. As students in our program are strongly focused on preparation for their professional accounting exams, we are pleased that they did not, on average, view the exercises as a waste of time. They agreed quite strongly that the movies made them more interested in the discussion. Since some of the criticisms of accounting education discussed in the introduction relate to lack of student interest, we view this result as very positive.

Table 5: Student Responses to the Film Exercises

\begin{tabular}{|l|c|}
\hline \multicolumn{1}{|c|}{ Statement } & Average \\
\hline Watching the movies before class was a waste of my time. & 2.18 \\
\hline I enjoyed the exercises based on the movies & 3.82 \\
\hline Watching the movies made me more interested in the discussion. & 3.93 \\
\hline
\end{tabular}

Average is the average response on a 5-point scale anchored by 5 (strongly agree) and 1 (strongly disagree).

\section{CONCLUSIONS}

On the whole, we believe that the film exercises were successful when measured by the cognitive and affective objectives that we set out earlier in this paper. These were not merely fun exercises, but real learning activities that provided opportunities for students to practice critical thinking and analytical skills and think about ethical values. The films motivated the students to learn, generating more than the usual amount of student participation, and the students took the tasks seriously and most completed these homework assignments. Tables 2,3 and 4 indicate that students felt that watching the movies helped them "think more clearly about corporate 
governance" and "understand internal control issues better," as well as provided them "with a clearer understanding of the personal impact of some ethical issues." While active learning techniques sometimes encounter student resistance, particularly if their prior experience has been limited in this respect, the class did not complain about this project. On the contrary, they seemed to find the exercises helpful and enjoyable, as shown by the responses in Table 5 .

As might be expected, we encountered some challenges in our first attempt to introduce this new learning activity. One logistical problem we faced was to ensure that students would be able to find copies of the movies that were assigned. For this reason, we were careful to select movies that were fairly recent and well known (popular) so that several copies would be available for rent at local video stores. Even so, with 120 students in a small city all needing to watch the same films, on occasion availability became an issue (especially for those who postponed renting the movies until the last few days before the discussions). To mitigate this, the instructor gave the class at least three weeks notice of each upcoming assignment. We also purchased five copies of each movie to lend to students to supplement what might be available at local video rental stores. In some cases, several students arranged to meet together to watch the movies as a group, thus promoting some degree of cooperative learning.

We recommend that any instructors intending to adopt this learning activity should carefully screen all movies they assign. Because films have a strong emotional impact, they are useful for stimulating class discussion. However, the instructor must ensure that the ideas being conveyed are not inappropriate or at odds with the course objectives. In addition, the instructor must warn students in advance of any material that some might deem offensive and provide alternative activities for those who choose not to participate in the exercise for this reason. Many popular films contain violence and language that some might consider inappropriate. We were diligent to warn students about this before they watched the films. Out of 120 students, only one objected to this and the instructor permitted her to substitute an alternative assignment.

Based on our experience, we also recommend, for the purpose of class discussion, that the instructor require all students to watch the same films. We did not do this for our ethics assignment where we attempted to promote cooperative learning by assigning different movies to different groups and then asking them to report back their findings to their colleagues. This proved to be less than optimal as students tended to relate only to the films that they had watched themselves. While this validates the use of movies to encourage involvement and emotional impact, students are unlikely to participate effectively in discussions of films that they have not viewed first hand.

The only conceptual limitation we encountered relates to a tendency by some students to dismiss some issues presented in the films as outdated. For example, because the events in Catch Me if You Can take place in the 1970s, several students assumed that new technology made available since then would prevent recurrences of similar incidents. While the instructor noted that these technologies can also be used by fraudsters, in the future we would be more prepared with recent statistics about the annual cost of fraud and examples of more recent cases to convince students that these problems are still very relevant. A similar issue arose with the corporate governance exercise. While students were aware of recent corporate scandals, some felt that the introduction of new legislation intended to increase the effectiveness of BODs has now solved the problem so that further concern is unwarranted. Again, the instructor might be in a better position to counter these notions if forearmed with information about incidents that have occurred after the implementation of Sarbanes Oxley.

Differences observed between the perceptions of those who participated in the exercises and those who did not suggest that films can have a significant impact on shaping students' beliefs. From the instructor's perspective, then, this learning activity was quite effective. The class discussions were often heated and most students were actively engaged. The short papers that were part of the assignments showed the usual array of effort - a few were poorly thought out, while most showed some analysis and an attempt to integrate classroom material and the film plots or characters. Many displayed excellent insight. In general, this set of papers was more enjoyable to read than was the case with other assignments during the term.

Thus, despite the minor challenges and limitations noted above, the authors plan to use this learning activity again. Overall, it was a very positive experience and we highly recommend that other accounting instructors experiment with it in the future. 


\section{ACKNOWLEDGEMENT}

We gratefully acknowledge the useful comments of Tony Dimnik, School of Business, Queen's University.

\section{AUTHOR INFORMATION}

Darlene Bay received her $\mathrm{PhD}$ at Washington State University. She is currently an Associate Professor of Accounting at Brock University in Ontario, Canada. Her primary research interests are ethics and personality characteristics (such as emotional intelligence, psychopathy and anti-intellectualism) of accountants and accounting students. She has a developing interest in cross cultural studies. She has published in Journal of Business Ethics, Issues in Accounting Education, and Accounting Education: An International Journal. E-mail: darlene.bay@brocku.ca.

Sandra Felton is a Chartered Accountant and received her $\mathrm{PhD}$ (Accounting) at the State University of New York at Buffalo. She is an Associate Professor of Accounting at Brock University, where she has served as Department Chair and as Associate Dean in the Faculty of Business. She has co-authored a financial accounting textbook and her research interests include financial reporting, accounting education, accounting history and the accountant's stereotype. Her work has appeared in various journals, including Accounting, Organizations and Society, Contemporary Accounting Research, and Journal of Business Ethics, and Issues in Accounting Education. E-mail: sfelton@brocku.ca. Corresponding author.

\section{REFERENCES}

1. Albrecht, W. \& Sack, R. (2000). Accounting Education: Charting a Course through a Perilous Future. Accounting Education Series, 16.

2. Anderson, L. \& Krathwohl, D. editors (2001). A Taxonomy for Learning, Teaching and Assessment: A Revision of Bloom's Taxonomy of Educational Objectives. Abridged edition. New York: Addison Wesley Longman, Inc.

3. Berger, J. \& Pratt, C. (1998). Teaching business communication ethics with controversial films. Journal of Business Ethics 17 (16), 1817-1824.

4. Bloom, B. editor. 1956. Taxonomy of Educational Objectives: The Classification of Educational Goals. Book 1 Cognitive Domain. New York: Longman, Inc.

5. Buchanan, D. \& Huczynski, A. (2004). Images of influence: 12 Angry Men and Thirteen Days. Journal of Management Inquiry 13 (4), 312-323.

6. Bumpus, M. (2005). Using motion pictures to teach management: refocusing the camera lens through the infusion approach to diversity. Journal of Management Education 29 (6), 792-816.

7. Champoux, J. (1999). Film as a teaching resource. Journal of Management Inquiry 8 (2), 206-228.

8. Connelly S., Helton-Fauth, W. \& Mumford, M. (2004). A managerial in-basket study of the impact of trait emotions on ethical choice. Journal of Business Ethics 51 (3), 245-267

9. Dirsmith, M. (1983). 'Obedience' in the classroom. Journal of Accounting Education 1 (2), 41-50.

10. Dixit, A. (2005). Restoring fun to game theory. Journal of Economic Education 36 (3), 205-220.

11. Eaton, T. \& Giacomino, D. (2000). Personal values of business students: differences by gender and discipline. Research on Accounting Ethics 7, 83-102.

12. Gaiacalone, R. \& Jurkiewicz, C. (2001). Lights, camera, action: teaching ethical decision making through the cinematic experience. Teaching Business Ethics 5 (1), 79-87.

13. Gaudine, A. \& Thorne, L. (2001). Emotion and ethical decision-making in organizations. Journal of Business Ethics 3, 175-187.

14. Grant, B. (1986). Experience and meaning in genre films. Film Genre Reader. Austin: University of Texas Press.

15. Griseri, P. (2002). Emotion and cognition in business ethics teaching. Teaching Business Ethics 6 (3), 371391.

16. Henrik, E. (2008). Mad as hell or scared stiff? The effects of value conflict and emotions on potential whistle-blowers. Journal of Business Ethics 80, 111-119.

17. Klein, S. 2002. The head, the heart and business virtues. Journal of Business Ethics 39, 347-359. 
18. Krathwohl, D, Bloom, B. \& Masai, B. (1964). Taxonomy of Educational Objectives: The Classification of Educational Goals. Handbook II: Affective Domain. New York: David McKay Company, Inc.

19. Leet, D. \& Houser, S. (2003). Economics goes to Hollywood: using classic films and documentaries to create and undergraduate economics course. Journal of Economic Education 34 (4), 326-332.

20. MacPhail, K. (2001). The other objective of ethics education: Rehumanizing the accounting profession-A study of ethics education in law, engineering, medicine and accountancy. Journal of Business Ethics 34, 279-298.

21. MacPhail, K. (2004). An emotional response to the state of accounting education: developing accounting students' emotional intelligence. Critical Perspectives in Accounting 15, 629-648.

22. Mallinger, M. \& Rossy, G. (2003). Film as a lens for teaching culture: balancing concepts, ambiguity and paradox. Journal of Management Education 27 (5), 608-617.

23. McAdams, T. \& Duclose, L. (1999). Teaching business ethics with computer-based media? A cautionary analysis. Teaching Business Ethics, 57-67.

24. Nosfinger, J. (1995). Barbarians at the gate: a capstone corporate finance project. Financial Practice and Education 5 (1), 118-122.

25. Pinac-Ward, S., Ward, D. \& Wilson, T. (1995). University accounting professors: an examination of personal values. Accounting Educators' Journal 7 (1), 39-53.

26. Rokeach, M. (1973). The Nature of Human Values. New York, NY: The Free Press.

27. Schweitzer, M. \& Gibson, D. (2008). Fairness, feelings and ethical decision-making: consequences of violating community standards of fairness. Journal of Business Ethics 77, 287-301.

28. Scott, W. (2006). Financial Accounting Theory ( $4^{\text {th }}$ Canadian ed.). Toronto: Prentice Hall.

29. Serey, T. (1992). Carpe Diem: lessons about life and management from Dead Poets Society. Journal of Management Education 16, 374-399.

30. Sexton, R. (2004). Hollywood ethics: developing ethical issues...Hollywood style. Journal of Economic Education 37 (4), 406-418.

31. Solomon, R. (1993). Ethics and Excellence: Cooperation and Integrity in Business. New York, NY: Oxford University Press.

32. Swindle, B., Phelps, L. \& Broussard, R. (1987). Professional ethics and values of certified public accountants. The Woman CPA. (April), 3-6.

33. Ten Bos, R. \& Willmott, H. (2001). Towards a post-dualist business ethics: Interweaving reason and emotion in working life. Journal of Management Studies 38(6), 769-793.

34. Thorne, L. (2001). Refocusing ethics education in accounting: an examination of accounting students' tendency to use their cognitive moral capability. Journal of Accounting Education 19, 103-117. 